\title{
An Investigation on Learning Climate at Sport High Schools
}

\author{
Halil Evren Şentürk ${ }^{1}$, T. Osman Mutlu² \\ ${ }^{1}$ Muğla Sitk1 Koçman University, Faculty of Sport Sciences, Department of Physical Education and Sports Teaching, \\ Muğla, Turkey \\ ${ }^{2}$ Muğla Sitkı Koçman University, Faculty of Sport Sciences, Department of Sport Administration, Muğla, Turkey \\ Correspondence: Halil Evren Şentürk, Muğla Sıtkı Koçman University, Faculty of Sport Sciences, Department of \\ Physical Education and Sports Teaching, Muğla, Turkey.
}

\author{
Received: July 4, 2019 Accepted: July 30, $2019 \quad$ Online Published: August 6, 2019 \\ doi:10.11114/jets.v7i9.4366 URL: https://doi.org/10.11114/jets.v7i9.4366
}

\begin{abstract}
Sport High Schools that activate in Turkey and where students who are skilled at sports have their secondary education are found to be suitable place to study on. In this study, it is aimed to study perception of teachers working and students studying in these institutions regarding learning climate. 342 teachers and 557 students that participated in the study voluntarily are considered to be the best universe taking part in the study in daily basis. In terms of data collection tool, Camur's "Learning Climate Scale" with its Turkish adaptation in the year 2006 is used by considering its sub-dimensions. The participants are reached through sharing prepared research form in on-line social media sport high school groups. In order to find out learning climate perception of both teachers and students, determining statistics is used where, t-test and one-way variance analysis is used for comparing independent samples based on demographic features, and in order to find the relationships in the study, Pearson $\mathrm{r}$ relationship analysis is applied. In the end of the analyses made, it is found out that physical education and sports teachers have negative impression about learning climate in sport high schools $(n=120$, mean $=3,304)$. Teachers of other fields working at sport high schools displayed highly negative impression $(n=222$, mean $=2,828)$. Students studying at these institutions on the other hand displayed lesser levels of negative impression when compared to teachers $(n=557$, mean=3,637). As a result, when sport high schools are investigated based on learning climate, it is concluded that; both teachers and students do not meet at an appropriate education environment due to current status in those schools.
\end{abstract}

Keywords: secondary education, sport, teacher, student, learning climate

\section{Introduction}

In order to achieve an appropriate level of learning in all phases of education, it is stated by the researchers (McBrien \& Brandt, 1997; Peker, 1993; Peker, 1995; Demirtas, 1999; Aydin, 2000; Acikgöz, 1996; Guclu, 2002; Basaran, 1996) that the first parameter is to form learning environment or climate appropriately. Then, combination of values should be paid attention at school together with culture, security and organisational structure. The reason is that this issue determines why different reactions are given to different factors than other schools. Schools having this structure that respects values and individuals approach to students as they are young individuals and this issue softens the authoritarian structure, serious rules and hierarchic structure at school and provide a more productive education environment (McBrien \& Brandt, 1997; Wei, 2003).

The concept of education climate (Yielding, 1993) can be considered relatively new when compared to the concepts of school or organisation climate. Hoy and Miskel (2005) define school environment as "The combination of internal features to differ one school from other and that affect behaviours of an individual". Ellis (1988) on the other hand defines the school having a good learning climate as a place with; cooperative and dedicated teachers, hard-working and enthusiastic students, intense understanding of respect and confidence, teachers and administrators assisting each-other. At schools with weak climate, there are; bored students, teachers behaving coldly and unfriendly to both students and each-other, and administrators who have no idea about the needs of teachers and who are ordering compulsory directives that also resist the change (Kaplan \& Geoffroy, 1990).

As stated by Aydın (2000), in environment with appropriate organisational climate; it is seed that more time and energy is reserved for education which is considered as the teacher's reason of existence. A positive school climate; develops 
performance of the employees, gives high moral and improve student success (Freiberg, 1998). Goddard, Hoy and Hoy (2000), student success and school climate depend on each other. As for Hoyle, English and Steffy'e (1985), "school environment is for the most part, one of the most significant tools of a successful teaching curriculum; without a climate creating harmony and good work, one can not expect high school success".

Schools developing a positive learning or school climate and an idiosyncratic positive education culture are found to be more effective than other schools (Kaplan \& Geoffroy, 1990). In this regard, in order for the success of their students; the effective school uses; physical environment, teaching tools and materials and all the resources of the school effectively. By so doing, physical and cognitive development of students will be achieved as well of emotional development (Balci, 2002; Becker, 1992; Johnson, 2000; Brown, 2002).

It is seen that, one of the factors required to develop an effective school is to create a confident, regular and positive learning climate (Becker, 1992; Chiang, 2003; Sammons et.al., 1995; Balci, 2002; Greaves, 2004). Kelley, Thornton and Daugherty (2005) on the other hand assert that; there is powerful, positive and mutual relationship between effectiveness and various climate variables.

In the light of said studies, it can be asserted that; for the favour of achieving absolute learning in all phases of education, it is primarily necessary to form learning environment or climate appropriately. Sport high schools that activate in Turkey and where students who are skilled at sport have their secondary education are found to be suitable place to study on. Sport high schools where academic and sportive success is observed less than other schools (Senturk, 2016) are expected to reach certain standards in terms of learning climate and effectiveness. Sport high schools that are expected to be among schools with high value in terms of learning climate and effectiveness are the field-specific schools to act as source for educating qualified people in the field of physical education and sport.

Starting from the concept of effective school, sport high schools on which many researches (Senturk, 2016) made are found to be suitable for development in terms of learning environment. In this regard, a study has been designed to include sport high schools among effective schools in terms of academic and sportive education where many skilled students in sport choose to study at. This study which is aimed at investigating the learning climate perception belongs to teachers and students in their schools is very significant to contribute to the field.

\section{Method}

\subsection{Participants}

In this study, it is aimed to find out perception of teachers working and students studying in these institutions regarding learning climate. The universe of the study is composed of 1192 teachers and 17544 students included in approximately 60 schools. 342 teachers and 557 students that participated in the study voluntarily are considered to be the best universe taking part in the study in daily basis. Cohen et.al., (2000) 's universe sampling table is taken into consideration while the sampling size of the research is determined and the number of participants in the sampling are found to be at the size to represent the universe.

\subsection{Data Collection Tools}

The study is a descriptive scanning study where it is also a study of analysis designed to determine learning climate in sport high schools. In terms of data collection tool, "Learning Climate Scale" developed by the combination of School Safety Centre located in Tennessee, USA and Schools at Lincoln district is used. This scale is being applied in these schools once in every three years. The more the points received at the scale increase, the more perceived positive learning climate or similarly concept of effective school perception increases. The scale which is adopted to Turkish by Camur in the year $2006(\alpha=, 97)$ is used in the study so as to describe only perceived general learning climate by disregarding its sub-dimensions. In choosing the sampling, for the fact that the only feature expected of the participants is determined as to study in or work at sport high schools, random sampling method is found to be the appropriate method to use. In this regard, the sampling method is similar to the random sampling method identified by Yildirim and Simsek (2005) and Cochran (2007). The participants are reached through sharing prepared research form in on-line social media sport high school groups in that it forms random sampling. Thanks to this method, the expected number of data is reached in a short time.

\subsection{The Analysis of Data}

Data obtained in the scale is collected and stored in electronic media to form very good $(\alpha=, 89)$ safety coefficient (Kline, 2005). After the data obtained from the scale is stored in electronic media, it is subjected first to normality test. Kurtosis and skewness values of the data is found to vary between 1,5 and -1,5 with normal distribution (Tabachnik \& Fidell, 2012). This data is analysed in this regard by parametric tests. In order to find out learning climate perception of both teachers and students, determining statistics is used where, $t$-test and one-way variance analysis is used for comparing independent samples based on demographic features. Besides, in order to find the relationships in the study, Pearson $r$ relationship analysis is applied. 


\section{Results}

The data obtained from analysis of the findings derived from teachers $(n=342$; ort. $=3,066)$ and students $(n=557$; mean. $=3,637$ ) are shown in tables.

When learning climate perceptions of participants are compared based on their geographical regions, it is found out that there are differences happening in both of the groups. This case represent statistically significant difference as $\mathrm{p}<, 05$ (Table 1).

Table 1. Comparison of Learning Climate Perception of Participants Based On Geographical Regions

\begin{tabular}{|c|c|c|c|c|c|c|c|c|}
\hline & Geographical Regions. & $\mathbf{N}$ & $\%$ & Mean & St.d. & $\mathbf{F}$ & $p$ & LSD \\
\hline \multirow[t]{8}{*}{ Teachers } & 1.Aegean & 32 & 9,4 & 3,221 & ,256 & 9,984 &, $002 * *$ & $1-6$ \\
\hline & 2.Marmara & 45 & 13,2 & 3,313 & ,348 & & & $1-7$ \\
\hline & 3.Central Anatolia & 57 & 16,7 & 3,163 & 464 & & & $2-6$ \\
\hline & 4.Mediterranean & 47 & 13,7 & 3,141 &, 274 & & & $2-7$ \\
\hline & 5.Black Sea & 64 & 18,7 & 2,967 & 298 & & & $3-7$ \\
\hline & 6.Eastern Anatolia & 66 & 19,3 & 2,859 & 389 & & & $4-7$ \\
\hline & 7.Southeast Anatolia & 31 & 9,1 & 2,795 &, 218 & & & \\
\hline & Total & 342 & 100,0 & & & & & \\
\hline \multirow[t]{8}{*}{ Students } & 1.Aegean & 56 & 10,1 & 3,821 & ,256 & 7,514 &, $013 *$ & $1-6$ \\
\hline & 2.Marmara & 72 & 12,9 & 3,913 &, 348 & & & $1-7$ \\
\hline & 3.Central Anatolia & 94 & 16,9 & 3,763 & 464 & & & $2-5$ \\
\hline & 4.Mediterranean & 82 & 14,7 & 3,641 &, 274 & & & $2-6$ \\
\hline & 5.Black Sea & 95 & 17,1 & 3,567 & ,298 & & & $2-7$ \\
\hline & 6.Eastern Anatolia & 110 & 19,7 & 3,459 & 389 & & & $3-7$ \\
\hline & 7.Southeast Anatolia & 48 & 8,6 & 3,295 & ,218 & & & $4-7$ \\
\hline & Total & 557 & 100,0 & \multicolumn{4}{|c|}{$* p<, 05 ; * * p<, 01$} & \\
\hline
\end{tabular}

When learning climate perceptions of participants are compared based on the sport high school having physical education centre, it is found out that there are differences happening in both of the groups. This case represent statistically significant difference as $\mathrm{p}<, 001$ (Table 2).

Table 2. Comparison of learning climate perception of participants based on existence of physical education centre.

\begin{tabular}{llllllll}
\hline & PE Center & $\mathbf{N}$ & $\mathbf{\%}$ & Mean & St.d. & t & $\mathbf{p}$ \\
\hline Teachers & Available & 116 & 33,9 & 3,254 &, 197 & 11,873 &, $000^{* *}$ \\
& Unavailable & 226 & 66,1 & 2,879 &, 201 & & \\
\cline { 2 - 7 } & Total & 342 & 100,0 & & & & \\
\hline Students & Available & 186 & 33,4 & 3,897 &, 324 & 13,367 &, $000^{* *}$ \\
& Unavailable & 371 & 66,6 & 3,378 &, 286 & & \\
\cline { 2 - 7 } & Total & 557 & 100,0 & $* p<, 05 ; * * p<, 01$ & & \\
& & & & & & \\
& & & &
\end{tabular}

When learning climate perceptions of teachers and students are compared based on their sex, it is found out that there are differences happening in both of the groups. This case represent statistically significant difference as $\mathrm{p}<, 05$ (Table $3)$.

Table 3. Comparison of learning climate perception of participants based on sex

\begin{tabular}{llllllll}
\hline & Cinsiyet & $\mathbf{N}$ & $\mathbf{\%}$ & Mean & St.d. & $\mathbf{t}$ & $\mathbf{p}$ \\
\hline Teachers & Male & 188 & 55,0 & 3,156 &, 096 & 8,563 &, $000^{* *}$ \\
& Female & 154 & 45,0 & 2,976 &, 134 & & \\
\cline { 2 - 7 } & Total & 342 & 100,0 & & & & \\
\hline Students & Male & 308 & 55,3 & 3,723 &, 284 & 7,917 &, $003 * *$ \\
& Female & 249 & 44,7 & 3,549 &, 265 & & \\
\cline { 2 - 7 } & Total & 557 & 100,0 & $* p<, 05 ; * * p<, 01$ & & \\
& & & & & & \\
& & &
\end{tabular}


When learning climate perceptions of participants are compared based on the number of physical education teachers working at sport high schools, it is found out that there are differences happening in both of the groups. This case represent statistically significant difference as $\mathrm{p}<, 001$ (Table 4).

Table 4. Comparison of learning climate perception of participants based on number of physical education teachers working at such high schools

\begin{tabular}{llllllll}
\hline & Num. of PE Teachers & $\mathbf{N}$ & $\mathbf{\%}$ & Mean & St.d. & $\mathbf{t}$ & $\mathbf{p}$ \\
\hline Teachers & 3 and under & 184 & 53,8 & 2,883 &, 104 & 12,763 &, $000^{* *}$ \\
& 4 and above & 158 & 46,2 & 3,249 &, 129 & & \\
\cline { 2 - 7 } & Total & 342 & 100,0 & & & & \\
\hline Students & 3 and under & 282 & 50,6 & 3,401 &, 218 & 10,183 &, $000^{* *}$ \\
& 4 and above & 275 & 49,4 & 3,873 &, 274 & & \\
\cline { 2 - 7 } & Total & 557 & 100,0 & $* p<, 05 ; * * p<, 01$ & & \\
\hline
\end{tabular}

When learning climate perceptions of participants are compared based on the number of students studying in sport high schools, it is found out that there are differences happening in both of the groups. This case represent statistically significant difference as $\mathrm{p}<, 05$ (Table 5).

Table 5. Comparison of learning climate perception of participants based on number of students studying in sport high schools

\begin{tabular}{llllllll}
\hline & Num. of Students & $\mathbf{N}$ & $\mathbf{\%}$ & Mean & St.d. & $\mathbf{t}$ & $\mathbf{p}$ \\
\hline Teachers & 180 and under & 163 & 47,7 & 2,967 &, 188 & 6,836 &, $014^{*}$ \\
& 181 and above & 179 & 52,3 & 3,165 &, 174 & & \\
\cline { 2 - 7 } & Total & 342 & 100,0 & & & & \\
\hline Students & 180 and under & 241 & 43,3 & 3,591 &, 352 & 5,903 &, $027^{*}$ \\
& 181 and above & 316 & 56,7 & 3,683 &, 306 & & \\
\cline { 2 - 7 } & Total & 557 & 100,0 & $* p<, 05 ; * * p<, 01$ & & \\
\hline
\end{tabular}

When learning climate perceptions of participants are compared based on number of classrooms in the sport high schools, it is found out that there are differences happening in both of the groups. This case represent statistically significant difference to teachers as $p<, 05$ where no difference is found among students. (Table 6).

Table 6. Comparison of learning climate perception of participants based on number of classrooms in sport high schools

\begin{tabular}{|c|c|c|c|c|c|c|c|}
\hline & Num.of Classrooms & $\mathbf{N}$ & $\%$ & Mean & St.d. & $\mathbf{t}$ & $\mathbf{p}$ \\
\hline \multirow[t]{3}{*}{ Teachers } & 8 and under & 208 & 60,8 & 2,979 & ,156 & 3,572 &, $043^{*}$ \\
\hline & 9 and above & 134 & 39,2 & 3,153 & ,193 & & \\
\hline & Total & 342 & 100,0 & & & & \\
\hline \multirow[t]{3}{*}{ Students } & 8 and under & 322 & 57,8 & 3,598 & ,205 & 2,906 &, 065 \\
\hline & 9 and above & 235 & 42,2 & 3,676 & ,196 & & \\
\hline & Total & 557 & 100,0 & \multicolumn{4}{|c|}{$* p<, 05 ; * * p<, 01$} \\
\hline
\end{tabular}

When learning climate perceptions of participants are compared based on number of classrooms in the sport high schools, it is found out that there are differences happening in both of the groups. This case represent statistically significant difference to teachers as $p<, 05$ where no difference is found among students. (Table 7).

Table 7. Comparison of learning climate perception of teachers based on their field

\begin{tabular}{llllllll}
\hline & Fields & $\mathbf{N}$ & $\mathbf{\%}$ & Mean & St.d. & $\mathbf{t}$ & $\mathbf{p}$ \\
\hline Teachers & Physical Education & 120 & 35,1 & 3,304 &, 109 & 7,382 &, $008^{* *}$ \\
& Other Fields & 222 & 64,9 & 2,828 &, 135 & & \\
\cline { 2 - 7 } & Total & 342 & 100,0 & & & &
\end{tabular}

When learning climate perceptions of teachers working in sport high schools are compared based on their fields, it is found out that there are there is statistically significant difference among teachers as $p<, 05$. (Table 8). 
Table 8. Comparison of learning climate perception of students based on types of sport

\begin{tabular}{llllllll}
\hline & Types of Sport & $\mathbf{N}$ & $\mathbf{\%}$ & Mean & St.d. & $\mathbf{t}$ & $\mathbf{p}$ \\
\hline Students & Individual Sports & 209 & 37,5 & 3,718 &, 216 & 3,362 &, $048^{*}$ \\
& Team Sports & 348 & 62,5 & 3,556 &, 283 & & \\
& Total & 557 & 100,0 & $*_{p<, 05 ; * * p<, 01}$ & & \\
& & &
\end{tabular}

When learning climate perceptions of students studying in sport high schools are compared based on the type of sport they are interested, it is found out that there are there is statistically significant difference among these students as $\mathrm{p}<, 05$. (Table 8).

Table 9. Relationship between learning climate perception of students and their demographic features

\begin{tabular}{llllll}
\hline Learning Climate & & Class Level & Age & Num. of Teachers & Num. of Students \\
\hline Teachers & $\mathrm{r}$ & - &, 112 &, 517 &, 312 \\
& $\mathrm{p}$ & - &, 345 &, $013^{*}$ &, $044^{*}$ \\
\hline Students & $\mathrm{r}$ &,- 348 &,- 401 &, 238 &, 192 \\
& $\mathrm{p}$ &, $001 * *$ &, $003 * *$ &, 089 &, 075 \\
\hline & & & & $* *_{p<, 05 ; * * p<, 01}$ \\
\hline
\end{tabular}

When the relationship between class, age, number of students and teachers at schools and their learning climate perception, it is found out that; in teachers, it is affected positively by number of teachers and students at schools where the same is negatively affected by age and class variant in students (Table 9).

\section{Discussion and Conclusion}

In the end of the statistical analyses made, it is found out that physical education and sports teachers have reflected not a very common impression about learning climate in sport high schools. However, teachers of other fields working at sport high schools displayed highly negative impression. Students studying at these institutions on the other hand displayed lesser levels of negative impression $(n=342$, mean $=3,066)$ when compared to teachers $(n=557$, mean $=3,637)$. Teachers working and students studying at sport high schools in Eastern and South-Eastern Anatolia region are found to have worse impression about learning climate. When the results are compared based on sex variable, it is found out that male teachers and students have better impression about learning climate. When the results are compared based on schools opportunities, it is found out that teachers and students have better impression about learning climate where the school has; more than 4 physical education teachers, physical education centre, 181 or more students and 9 or more classrooms. Besides, it is found out that, students in these sport high schools who deal with individual sports have better impression about learning climate than the students interested in team sports.

When the related studies in the literature are controlled, it is found out that; in order for teachers working in these institutions to elevate learning carried out at education environment to highest levels and create opportunities for students to be interested in their own education; it is extremely necessary to create an appropriate learning environment at school. As a result, when sport high schools are investigate based on learning climate, it is concluded that; both teachers and students do not meet at an appropriate education environment due to current status in those schools ( such as; facility, equipment, teacher adequacy, teaching programs etc.).

In the study conducted by Godber in the year 2002, it is found out that student and parent ideas coincide with the ideas of administrators and teachers respectively and there are differences between these two ideas. A similar case is observed in this current study.

There is a positive relationship between attitudes of students towards school and school climate. The attitude of the students towards teachers relies on intra-class attitudes of teachers and their dedication to teaching methods. Besides, it is found out by Amick in the year 2004 that; there is positive relationship between the school climate and teachers attitude about students discipline.

Teacher's learning or school climate degreases especially in general high schools and vocational school as it is found out in the study of Camur (2006). This finding suggests that there is a problem of fulfilment among teachers working in these types of high schools. Studies made on occupational fulfilment shows that one of the most important factors affecting teacher's professional fulfilment is the success of students. As a result, like in general and vocational high schools, success level of students studying in sport high schools is not enough to boost teachers professionally.

When the results are compared based on sex variable, it is found out that male teachers have more positive perception 
of their school climate than the female teachers. This finding is similar to the findings obtained by Rivers (2003) and Camur (2006). According to these studies, female teachers are more interested in their school climate than the male teachers. As stated by John and Taylor (2002), dedication of female teachers to their organisations is more than male teachers. However, this situation is observed as just the opposite in teachers working in sport high schools.

In the study, it is found out that $9^{\text {th }}$ and $10^{\text {th }}$ grade students display more positive impression about their school climate than the upper-class students. In another words, the more you study at school, the more negative impression you obtain. Final year students having more negative impression can be interpreted as two sided. This can derive from factors such as; their expectations not to be met by the school administration, their lack of eagerness to classes in the final year due to their enthusiasm to prepare for University Exam, lack of communication or lack of self-esteem. The reason can also be the fact that they are in their final year and their sense of belonging to school decreases. Ziazi (2004) and Camur (2006) mentioned similar cases in their studies.

\section{Recommendations}

With the current conditions, due the fact that learning climate perception of teachers and students of sport high schools is highly law, it can lead failure in reaching academic and sportive goals. Thus, it is necessary for Ministry of National Education and Ministry of Youth and Sport to create more renovative and supportive environments.

\section{References}

Acikgoz, K. U. (1996). Etkili ogrenme ve ogretim. Izmir: Kanyilmaz Matbaasi.

Amick, C. S. (2004). Faculty, parent, and student perceptions of school climate in selected Missouri public schools studied from the Missouri School Improvement Program, Southern Illinois University at Carbondale. AAT 3136267 ProQuest Dissertations and Theses.

Aydin, M. (2000). Çagdas egitim denetimi (4. baski). Ankara: Hatipoglu Yayinevi.

Balci, A. (2002). Etkili okul: kuram, uygulama ve arastirma (3. baski). Ankara: PegemA Yayinevi.

Basaran, I. E. (1996). Turk egitim sistemi. Ankara: Gul Yayinevi.

Becker, M. (1992). An effective school primer. American Association of School Administrators. Arlington. ED 368 044, ERIC Database.

Brown, S. M. (2002). Strategies that contribute to nontraditional/adult student development and persistence. PAACE Journal of Lifelong Learning, 11, 67-76.

Camur, E. (2006). Liselerde ogrenme iklimine iliskin yonetici, ogretmen, veli ve ogrenci gorusleri. Yayimlanmamis yuksek lisans tezi, Ege Universitesi, Izmir.

Chiang, L. H. (2003). Shaping positive school culture: judgements of school administrators. Conference of the Midwestern Educational Research Association, Columbus, ERIC Database, ED 482-349.

Cochran, W. G. (2007). Sampling techniques. John Wiley \& Sons.

Cohen, L., Manion, L., \& Morrison, K. (2002). Research methods in education. Routledge. https://doi.org/10.4324/9780203224342

Demirtas, H. (1999). Okul mudurleri icin etkili olma yollari. Ogretmen Dunyasi, 20(240), 16-19.

Ellis, R. J. (1988) . Self-monitoring and leadership emergence in groups. Personality and Social Psychology Bulletin, 14. https://doi.org/10.1177/0146167288144004

Freiberg, H. J. (1998). Measuring school climate: Let me count the ways. Educational Leadership, 56(1), 22-26.

Godber, Y. E. (2002). School climate: understanding parent perspectives to strengthen family-school relationships. University of Minnesota, ProQuest Dissertations and Theses, AAT 3056317.

Goddard, R. D., Hoy, W. K., \& Hoy, A. W. (2000). Collective teacher efficacy: Its meaning, measure, and impact on student achievement. American Educational Research Journal, 37(2), 479-507. https://doi.org/10.3102/00028312037002479

Greaves, C. L. (2004). Organizational climate and elementary student achievement in a small, rural Delaware school district. Wilmington College (Delaware), ProQuest Dissertations and Theses, AAT 3139895,

Guclu, N. (2002). Orgut kulturu. Sosyal Bilimler Dergisi, 147-159.

Hoy, W., \& Miskel, C. (2005). Education administration: Theory, research, and practice (7th ed.). New York: McGraw-Hill. 
Hoyle, J., English, F., \& Steffy, B. (1985). Skills for successful leaders. Arlington, VA: American Association of School Administrators.

John M. C., \& Taylor V. J. W. (2002). Leadership approach, school climate, and teacher commitment: a philippine perspective. Christian Education Journal, Talbot School of Theology, 6(1), Spring.

Johnson, R. (2000). The authority of the student evaluation questionnaire. Teaching in Higher Education, 5(4), 419-434. https://doi.org/10.1080/713699176

Kaplan, L. S., \& Geoffroy, K. E. (1990). Enhancing the school climate: new opportunities for the counselor. School Counselor, September, 38(1).

Kelley, R. C., Thornton, B., \& Daugherty, R. (2005). Relationships between measures of leadership and school climate. Education, Fall, 126(1).

Kline, R. B. (2005). Principle and practice of structural equation modeling. New York: The Guilford Press.

McBrien J. L., \& Brandt R. S. (1997). The language of learning: a guide to education terms. Alexandria, VA: Association for Supervision and Curriculum Development.

Peker, O. (1993). Okullarda orgutsel havanin cozumlenmesinde bir yontem. Amme Idaresi Dergisi, 26(4).

Peker, O. (1995). Yonetimi gelistirmenin surekliligi. No: 258. Ankara: TODAIE Yayinlari.

Rivers, W. J. (2003). Relationships between teacher-perceived school climate and school climate outcomes. Waldosta State University. ProQuest Dissertations and Theses, AAT 0807730.

Sammons, P., Hillman, J., \& Martimore P. (1995). Key characteristics of effective schools: a review of school effectiveness research. London University, Institution of Education. ERIC Database, ED 389-826.

Senturk H. E. (2016). Avrupa Birligi Spor Egitimi Temelinde Turkiye Spor Liselerinin Islevsellik Acisindan Durum Analizi. Yayinlanmamis Doktora Tezi, Celal Bayar Universitesi, Saglik Bilimleri Enstitusu, Beden Egitimi ve Spor Anabilim Dali, Manisa.

Tabachnik, B. G., \& Fidell, L. S. (2012). Using multivariate statistics (6. ed.). Boston: Pearson.

Wei, L. T. (2003). Organizational climate and effectiveness in junior-middle schools in P. R. China. University of Regina. ProQuest Dissertations and Theses, AAT MQ92858.

Yielding, A. C. (1993). Interface between educational facilities and learning climate. Doctoral Dissertation, University of Alabama. ERIC Database, ED 472268.

Yildirim, A., \& Simsek, H. (2005). Sosyal bilimlerde nitel arastirma yontemleri. Ankara: Seckin Yayincilik.

Ziazi, Z. R. (2004). Adolescents' bonding to school: the impact of perceived school climate pathways on middle school students' bonding to school. Michigan State University, Michigan: USA. ProQuest Dissertations and Thesis.

\section{Copyrights}

Copyright for this article is retained by the author(s), with first publication rights granted to the journal.

This is an open-access article distributed under the terms and conditions of the Creative Commons Attribution license which permits unrestricted use, distribution, and reproduction in any medium, provided the original work is properly cited. 